MAREK SZKLARCZYK

WOJCIECH WESOLOWSKI

MARCELINA WAJDZIK

ANNA SZLACHTOWSKA

BEATA DOMNICZ

STEFAN STOJALOWSKI

Zakład Genetyki, Hodowli Roślin i Nasiennictwa; Instytut Biologii Roślin i Biotechnologii, Wydział Biotechnologii i Ogrodnictwa, Uniwersytet Rolniczy w Krakowie

Kierownik Tematu: dr hab. Marek Szklarczyk Zakład Genetyki, Hodowli Roślin i Nasiennictwa

Instytut Biologii Roślin i Biotechnologii Wydział Biotechnologii i Ogrodnictwa, Uniwersytet Rolniczy

w Krakowie Al. 29 Listopada 54, 31-425 Kraków; 12662 5328; e-mail: marek.szklarczyk@urk.edu.pl

Prace zostały wykonane $w$ ramach badan podstawowych na rzecz postęp biologicznego w produkcji roślinnej na podstawie decyzji Ministra Rolnictwa i Rozwoju Wsi nr HOR.hn.802.8.2018, Zadanie 97.

\title{
Identyfikacja genów odpowiedzialnych za przywracanie płodności i samozgodność u wybranych roślin warzywnych
}

\section{Identification of genes responsible for fertility restoration and self-compatibility in selected vegetable plants}

\footnotetext{
Słowa kluczowe: cytoplazmatyczna męska sterylność, genotypowanie, geny restorerowe, markery molekularne, samozgodność
}

\section{TEMAT BADAWCZY 1: UZYSKANIE POPULACJI SEGREGUJACYCH POD WZGLEDEM CECH STERYLNOŚCI/PŁODNOŚCI ORAZ SAMOZGODNOŚCI/SAMONIEZGODNOŚCI}

\section{Cele tematu}

1) Uzyskanie populacji marchwi i cebuli $\mathrm{z}$ segregacją genów odpowiedzialnych za przywracanie płodności. 2) Uzyskanie materiałów kapusty z segregacją genów odpowiedzialnych za samozgodność / samoniezgodność.

\section{Opis wyników}

Wysiano osiem potomstw BC marchwi uzyskanych w rezultacie zapylenia roślin męskosterylnych pyłkiem heterozygotycznych roślin męskopłodnych. W sześciu potomstwach występowała cytoplazma Sa, natomiast w dwóch - Sp. W rezultacie przeprowadzonych upraw uzyskano korzenie wysadkowe, które po zbiorze z pola 
umieszczono w chłodni. Na bazie tych korzeni w kolejnym sezonie wegetacyjnym planuje się uzyskać kwitnące rośliny do analizy fenotypu płodności.

Doprowadzono do kwitnienia trzy populacje BC cebuli. W czasie kwitnienia roślin wizualnie sprawdzano u nich obecność pyłku. Wizualna ocena płodności była weryfikowana poprzez mikroskopową analizę żywotności pyłku. Dwie z badanych populacji segregowały na rośliny męskopłodne i męskosterylne w oczekiwanym stosunku 1:1. Natomiast w jednej populacji wystąpiły wyłącznie rośliny męskosterylne. W ramach prac nad cebulą uzyskano także wysadki dwóch potomstw z cytoplazmą C, w których oczekuje się segregacji pod względem fenotypu płodności.

Po udanej jarowizacji doprowadzono do kwitnienia rośliny F3 kapusty, na których wykonano samozapylenia w otwartym kwiecie (dla oceny poziomu samoniezgodności) oraz w pąku (dla reprodukcji materiału). Analizowane rośliny F3 segregowały pod względem fenotypu samoniezgodności/samozgodności. Miarą tego fenotypu był stosunek liczby nasion do liczby łuszczyn, który zawierał się $\mathrm{w}$ przedziale od 0 do 21 . Podobnej analizie fenotypowej poddano także cztery rody wyprowadzone w celu weryfikacji dziedziczenia samozgodności. W nich także wystąpiła segregacja, ale maksymalne wartości wspomnianego stosunku były wyraźnie mniejsze.

\section{Wnioski}

- Uzyskano wysadki ośmiu potomstw marchwi i dwóch potomstw cebuli, w których oczekuje się segregacji na rośliny męskosterylne i męskopłodne.

- Segregacja fenotypowa w obrębie dwóch kwitnących populacji cebuli i wszystkich kwitnących materiałów kapusty gwarantuje ich przydatność do analiz markerowych.

\section{TEMAT BADAWCZY 2: GENOTYPOWANIE METODĄ GBS - POSZUKIWANIE POLIMORFIZMÓW DNA SPRZĘŻONYCH Z BADANYMI CECHAMI}

\section{Cele tematu}

1) Masowa identyfikacja polimorfizmów sekwencyjnych u roślin cebuli różniących się statusem płodności. 2) Masowa identyfikacja polimorfizmów sekwencyjnych u roślin kapusty różniących się statusem samoniezgodności.

\section{Opis wyników}

Genotypowaniu poddano trzy populacje cebuli segregujące na rośliny męskosterylne i męskopłodne - 8, 307 i 308, oraz jedną populację kapusty - o numerze 2 - segregującą na rośliny samozgodne i samoniezgodne. Analiza ta była wykonywana w ramach usługi zleconej firmie Novogene (Chiny). Do sekwencjonowania wysokoprzepustowego wykorzystano platformę firmy Illumina. Zastosowano wariant sekwencjonowania ze sparowanymi końcami i 150 cyklami syntezy (PE150). W przypadku populacji kapusty długość odczytanych sekwencji wahała się od ok. 200 do ok. $430 \mathrm{Mb}$ dla pojedynczej rośliny. Wskaźniki Q20 i Q30 wyniosły odpowiednio 94 i 86\%, a udział par GC 40-42\%.

\section{Wnioski}

- Dla obydwu badanych populacji uzyskano wystarczającą ilość danych sekwencyjnych. Przeciętne pokrycie sekwencji unikalnych u pojedynczej rośliny wyniosło ok. 0,5-1×. 
- Wysoki procent nukleotydów osiągających wskaźniki jakości Q20 i Q30 gwarantuje przydatność otrzymanych danych sekwencyjnych dla analiz bioinformatycznych zmierzających do identyfikacji polimorfizmów pojedynczego nukleotydu (SNP).

\section{TEMAT BADAWCZY 3: ANALIZY BIOINFORMATYCZNE — IDENTYFIKACJA GENOTYPÓW I MAPOWANIE POLIMORFIZMÓW}

\section{Cele tematu}

Określenie genomowej lokalizacji zidentyfikowanych markerów GBS oraz genów kontrolujących przywracanie płodności u cebuli oraz samozgodność u kapusty.

\section{Opis wyników}

W przypadku roślin kapusty (populacja) przefiltrowane odczyty sekwencyjne były mapowane do sekwencji genomu referencyjnego (GenBank: JJMF00000000.1) — średni odsetek zmapowanych odczytów wyniós $94,7 \%$. Średnio 13\% genomu referencyjnego było pokryte odczytami sekwencyjnymi (wykazywało pokrycie przynajmniej $1 \times$ ). W wyniku mapowania odczytów do genomu referencyjnego zidentyfikowano ok. 1,5 mln polimorfizmów sekwencyjnych, które następnie poddawano kilkustopniowej filtracji. Obejmowała ona kolejno selekcję markerów: biallelicznych o wysokiej jakości, z maksymalnie pięcioma nieokreślonymi genotypami, o genotypach odpowiadających charakterowi badanej populacji, o właściwej segregacji oraz oddalonych od siebie o więcej niż $10 \mathrm{~kb}$. W rezultacie do mapowania genetycznego wykorzystano ok. 700 markerów. Uzyskano dziewięć grup sprzężeń odpowiadających dziewięciu chromosomom kapusty. Całkowita długość mapy wynosiła $721 \mathrm{cM}$ ze średnią długością pojedynczej grupy sprzężeń wynoszącą 80,1 cM. Analiza programem R/qtl nie wykazała obecności QTLi skorelowanych z cechą samozgodności — wartość LOD dla żadnego zmapowanego markera nie przekroczyła wartości krytycznej.

\section{Wnioski}

- Przy wykorzystaniu technologii GBS otrzymano dane sekwencyjne, które pozwoliły na wydajną identyfikację markerów GBS i otrzymanie — przynajmniej lokalnie wysoko wysyconych map genetycznych. Dzięki dostępności sekwencji referencyjnej określono chromosomową lokalizację zidentyfikowanych grup sprzężeń.

- Regresyjne mapowanie interwałowe nie wykazało obecności QTLa mającego wpływ na ekspresję cechy samozgodności w populacji $\mathrm{C} 2$.

\section{TEMAT BADAWCZY 4: GENOTYPOWANIE MARKERAMI MIKROSATELITARNYMI (CEBULA)}

\section{Cele tematu}

Zmapowanie chromosomowo-specyficznych markerów mikrosatelitarnych w obrębie grup sprzężeń utworzonych z markerów GBS.

\section{Opis wyników}

Analizami objęto trzy populacje cebuli - AI/10, AI/15 i 601, które segregowały na rośliny męskosterylne i męskopłodne. Populacje te genotypowano markerami SSR wytypowanymi $\mathrm{W}$ poprzednim roku badań. Rośliny $\mathrm{z}$ populacji AI/10 poddano 
genotypowaniu przy użyciu markerów AMS-10, AMS-12 oraz AMS-23; rośliny z populacji AI/15 poddano genotypowaniu przy użyciu markerów AMS-08, AMS-10 oraz AMS-12; natomiast rośliny z populacji 601 poddano genotypowaniu przy użyciu markerów AMS-10 oraz AMS-23. Analiza profili elektroforetycznych potwierdziła segregację tych markerów w odpowiednich populacjach. Mapy markerów GBS uzyskane w poprzednich latach próbowano uzupełnić o loci segregujących markerów SSR. Udało się to tylko dla populacji 601 - markery AMS10 i AMS23 zmapowały się do dwóch różnych grup sprzężeń.

\section{Wnioski}

- Grupa sprzężeń z markerem AMS-10 reprezentuje chromosom II a grupa sprzężeń $\mathrm{z}$ markerem AMS-23 — chromosom III.

\section{TEMAT BADAWCZY 5: KONWERSJA SPRZEŻONYCH Z DOCELOWYMI GENAMI POLIMORFIZMÓW DNA W MARKERY SEKWENCYJNIE SPECYFICZNE — CAPS, TETRA-PRIMER ARMS-PCR ORAZ TAQMAN}

\section{Cele tematu}

Opracowanie markerów PCR do wnioskowania o obecności alleli restorerowych i alleli (allelu) samozgodności.

\section{Opis wyników}

Analizy przeprowadzono dla jednej populacji marchwi, jednej populacji cebuli oraz dla dwóch populacji kapusty. Populacje marchwi i cebuli segregowały na rośliny męskosterylne i męskopłodne. $Z$ kolei rośliny z populacji kapusty cechował zróżnicowany poziom samozgodności. $Z$ każdej populacji analizowano po pięć roślin o zróżnicowanych fenotypach - męskosterylnych i męskopłodnych (marchew, cebula), samoniezgodnych i najsilniej samozgodnych. Markery CAPS projektowano na bazie wskazań programu VCF2CAPS (Wesołowski). Dla większości takich markerów uzyskano monomorficzne profile elektroforetyczne. Polimorfizm odnotowano tylko po użyciu czterech markerów marchwianych oraz po użyciu jednego markera kapuścianego, jednak różnicował on rośliny tylko w jednej $\mathrm{z}$ dwóch badanych populacji kapusty. Wszystkie wykryte markery polimorficzne wykazywały kosegregację z odpowiednimi fenotypami.

\section{Wnioski}

- Dla populacji marchwi z cytoplazmą Sp zidentyfikowano cztery polimorficzne markery. Wykazywały one kosegregację z fenotypem płodności/sterylności roślin.

— Dla jednej z badanych populacji kapusty zidentyfikowano jeden marker polimorficzny. Wykazywał on kosegregację z fenotypem smozgodności/samoniezgodności roślin. 